\title{
Hybridization of phosphate-methylated DNA and natural oligonucleotides : implications for protein-induced DNA duplex destabilization
}

Citation for published version (APA):

Genderen, van, M. H. P., Kook, L. H., \& Buck, H. M. (1989). Hybridization of phosphate-methylated DNA and natural oligonucleotides: implications for protein-induced DNA duplex destabilization. Recueil des Travaux Chimiques des Pays-Bas, 108(1), 28-35. https://doi.org/10.1002/recl.19891080106

DOI:

10.1002/recl.19891080106

Document status and date:

Published: 01/01/1989

Document Version:

Publisher's PDF, also known as Version of Record (includes final page, issue and volume numbers)

Please check the document version of this publication:

- A submitted manuscript is the version of the article upon submission and before peer-review. There can be important differences between the submitted version and the official published version of record. People interested in the research are advised to contact the author for the final version of the publication, or visit the DOI to the publisher's website.

- The final author version and the galley proof are versions of the publication after peer review.

- The final published version features the final layout of the paper including the volume, issue and page numbers.

Link to publication

\footnotetext{
General rights

- You may freely distribute the URL identifying the publication in the public portal. follow below link for the End User Agreement:

www.tue.nl/taverne

\section{Take down policy}

If you believe that this document breaches copyright please contact us at:

openaccess@tue.nl

providing details and we will investigate your claim.
}

Copyright and moral rights for the publications made accessible in the public portal are retained by the authors and/or other copyright owners and it is a condition of accessing publications that users recognise and abide by the legal requirements associated with these rights.

- Users may download and print one copy of any publication from the public portal for the purpose of private study or research.

- You may not further distribute the material or use it for any profit-making activity or commercial gain

If the publication is distributed under the terms of Article 25fa of the Dutch Copyright Act, indicated by the "Taverne" license above, please 


\title{
Hybridization of phosphate-methylated DNA and natural oligonucleotides. Implications for protein-induced DNA duplex destabilization
}

\author{
Marcel H. P. van Genderen*, Leo H. Koole and Henk M. Buck \\ Department of Organic Chemistry, Eindhoven University of Technology, 5600 MB Eindhoven, \\ The Netherlands \\ (Received June 29th, 1988)
}

\begin{abstract}
Duplex stabilities have been determined for several hybrids of phosphate-methylate oligonucleotides and natural DNA or RNA using UV hyperchromicity experiments. These hybrid have a higher stability than the corresponding natural duplexes, due to the absence of interstranc electrostatic repulsions. Comparison with stability data for hybrids of other neutral oligonucleotidet (with phosphate-ethylated and methyl phosphonate linkages) and natural DNA or RNA revealee that differences in stability could be attributed mainly to steric and stereoelectronic factors. Fo phosphate-ethylated oligonucleotides, hybridization with a natural strand is strongly influenced $b$ steric interactions of the ethyl group. Hybridization with RNA, which requires a tight A-type confo mation, is therefore difficult and the ethyl orientation (inward or outward, depending on th phosphorus configuration) determines the strength of the association with natural DNA. In meth phosphonate systems, it appears that the presence of a $\mathrm{P}-\mathrm{C}$ bond disturbs the helix conformatio for stereoelectronic reasons. This leads to a weaker hybridization with DNA and RNA for longe strands. Phosphate-methylated oligonucleotides are found to have an optimal combination of ster and stereoelectronic factors and form the strongest hybrids with natural DNA. Absence intrastrand phosphate-phosphate repulsions causes a slightly different conformation for phosphat methylated DNA, which is evident in the cooperative character of the hybridization with natur DNA. A thermodynamic model for this cooperativity is presented and the model studies are extende to protein-DNA complexes in which phosphate charges are also shielded. The preliminary resul suggest that protein association can destabilize a DNA duplex, thus providing a possible mechanis for the action of DNA unwinding enzymes.
\end{abstract}

\section{Introduction}

Synthetic DNA oligomers with backbone modifications are useful as model compounds for studying DNA structure and dynamics ${ }^{1}$ and as probes for elucidating the stereochemistry in enzymatic cleavage of oligonucleotide strands ${ }^{2}$. Systems in which the charge of the phosphate groups is eliminated, e.g. phosphate triesters and phosphonates, have received particular attention, because of their resistance to breakdown by nucleases ${ }^{3}$ and their easy transport through cell membranes as a result of their lipophilic character ${ }^{4}$. The absence of the negative phosphate charge also minimizes electrostatic repulsions between the strands in a DNA duplex, thus raising the duplex stability ${ }^{5}$. These properties have led to the suggestion that neutral DNA analogues are well-suited for anti-sense hybridization techniques, where a specific genomic sequence is blocked by strong association with a complementary probe ${ }^{6}$.

In recent years, we have studied phosphate-methylated DNA systems, which are now easily available via new synthetic routes ${ }^{5,7}$. It has already been demonstrated that methylation of the phosphate groups in oligothymidine strands gives rise to a new duplex structure, based of thymine-thymine pairing ${ }^{8}$. In this duplex, the $5^{\prime} \rightarrow$ vectors run in the same direction, i.e. parallel, due to the symmetrical base pairing. Since pyrimidine-pyrimidint association forces the backbones into close proximity phosphate charge shielding is essential for the formation 0 the parallel duplex. Very recently, this parallel duplex wa also observed with cytosine-cytosine base pairing in the phosphate-methylated dinucleotide $\mathrm{d}(\mathrm{Cp}(\mathrm{OMe}) \mathrm{C})$ excli: sively for the $S_{\mathrm{P}}$ configuration on phosphorus ${ }^{9 \mathrm{a}}$. It is 0 interest to note that complexation of the phosphate group with a polycationic protein (e.g. polylysine or polyornithinel can accomplish the same effect as methylation ${ }^{9 a, 10}$. This provides the possibility of extrapolating the results witt phosphate-methylated systems to protein-DNA inter actions, which are important in understanding the action 0 specific enzymes which destabilize the DNA duplex. In this paper, we present our results on the hybridization phosphate-methylated oligomers and natural DNA RNA. The duplex stabilities will be compared to those found for other types of neutral DNA. The discussion wit focus on phosphate-ethylated and methyl phosphonate ol system protoci and $(C$ which phospl coil m phospl establi experis aqueor for the indepe syster was $\mathrm{c}$ ${ }^{1} \mathrm{H}$ NN shift $\varepsilon$ hydrol A clea the $b$ sonan of $1: 1$ all ph mixtu]

Table I

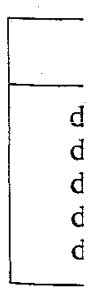

Table

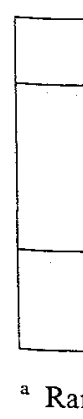


gonucleotides, which have been extensively studied by Miller et al. ${ }^{3 \mathrm{a}, 6 \mathrm{c}, 11}$ and by Pless and $T s^{\prime} o^{12}$. For duplexes between phosphate-methylated and natural DNA, a more detailed study has been carried out, which provides insight into the structural properties of the phosphate-methylated strand.

\section{Results}

The various types of neutral DNA oligomers are identified using the following notation: phosphate-methylated, $\mathrm{p}(\mathrm{OMe})$; phosphate-ethylated, $\mathrm{p}(\mathrm{OEt}) ;$ methyl phosphonate, $\mathrm{p}(\mathrm{Me})$. The synthesis of the phosphate-methylated<smiles>COP(=O)(OC)OC</smiles>

p (OMe)

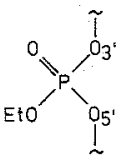

plOEt)

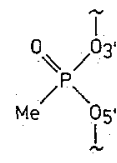

$p(M e)$ systems was achieved using a modified phosphoramidite protocol $^{13}$. New base-protecting groups such as amidine ${ }^{14}$ and (9-fluorenyl)methoxycarbonyl ${ }^{7,15}$ (Fmoc) were used, which can be removed under conditions that leave the phosphate triesters intact (see Experimental). Duplex $\rightleftarrows$ coil melting temperatures ( $T_{\mathrm{m}}$ values) for hybrids between phosphate-methylated and natural DNA or RNA were established in all cases by means of UV hyperchromicity experiments. Measurements were performed in a salt-free aqueous solution, since it has been shown repeatedly that, for these types of neutral/natural hybrids, the $T_{\mathrm{m}}$ value is independent of the ionic strength of the solution ${ }^{6 c}$. For the system d(Ap(OMe)Ap(OMe)A $) \cdot \operatorname{poly}(\mathrm{dT})$, the $T_{\mathrm{m}}$ value was corroborated using variable temperature $500-\mathrm{MHz}$ ${ }^{1} \mathrm{H}$ NMR spectroscopy in $\mathrm{H}_{2} \mathrm{O}$ by following the chemical shift and linewidth of the imino protons involved in the hydrogen bonding (see Fig. 1).

A clear melting transition occurs around $40^{\circ} \mathrm{C}$, as is seen in the broadening and upfield shifting of the imino resonance $^{16}$. All $T_{m}$ measurements were performed at a ratio of $1: 1$ for complementary bases, unless stated otherwise. Of all phosphate-methylated oligonucleotides, diastereomeric mixtures were used with respect to the phosphorus configu-

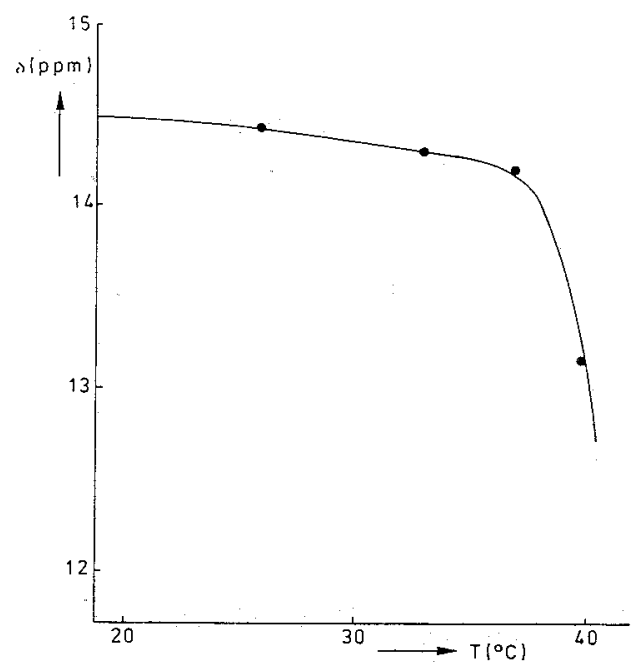

Fig. 1. ${ }^{1} H N M R$ chemical shift of the imino protons in the system d(Ap $(O M e) A p(O M e) A) \cdot \operatorname{poly}(d T)$ vs. temperature.

ration. It will be shown (vide infra) that the phosphorus chirality in phosphate-methylated DNA does not influence the stability of hybrids with natural systems. Table I lists the $T_{\mathrm{m}}$ values of the systems studied, and the natural reference duplex $\mathrm{d}\left(\mathrm{A}_{3}\right) \cdot \operatorname{poly}(\mathrm{dT})$ has a $T_{\mathrm{m}}$ of $20^{\circ} \mathrm{C}$.

From the difference of $21^{\circ} \mathrm{C}$ in $\mathrm{T}_{\mathrm{m}}$ value between this reference system and the corresponding phosphatemethylated system, it is obvious that a stabilization of the duplex structure indeed occurs upon neutralization. It can also be clearly seen that formation of $\mathrm{G}-\mathrm{C}$ base pairs gives rise to a much higher duplex stability than found with $\mathrm{A}-\mathrm{T}$ base pairs. Table II contains the stability data of the hybrids between methyl phosphonate and natural DNA or RNA, as reported by Miller et al. in several publications ${ }^{6 c, 11}$. The results obtained on hybrids of phosphate-ethylated oligomers and natural systems shown in Table II come mainly from the work of Miller et al. ${ }^{3 a}$ and Pless and $T s^{\prime} o^{12}$.

As a consequence of the independence of ionic strength (vide supra), the results given in Tables $I$ and II can be compared to abstract the various factors which determine the duplex stabilities of the neutral/natural systems.

Table I $T_{\mathrm{m}}$ values for hybrids between phosphate-methylated oligonucleotides and natural DNA or RNA.

\begin{tabular}{|l|c|c|c|}
\hline System & $T_{\mathrm{m}}\left({ }^{\circ} \mathrm{C}\right)$ & System & $T_{\mathrm{m}}\left({ }^{\circ} \mathrm{C}\right)$ \\
\hline $\mathrm{d}(\mathrm{Ap}(\mathrm{OMe}) \mathrm{A}) \cdot \operatorname{poly}(\mathrm{dT})$ & 30 & $\mathrm{~d}(\mathrm{Ap}(\mathrm{OMe}) \mathrm{A}) \cdot \operatorname{poly}(\mathrm{U})$ & 13 \\
$\mathrm{~d}(\mathrm{Ap}(\mathrm{OMe}) \mathrm{Ap}(\mathrm{OMe}) \mathrm{A}) \cdot \operatorname{poly}(\mathrm{dT})$ & 41 & $\mathrm{~d}(\mathrm{Ap}(\mathrm{OMe}) \mathrm{Ap}(\mathrm{OM}) \mathrm{A}) \cdot \operatorname{poly}(\mathrm{U})$ & \\
$\mathrm{d}\left([\mathrm{Ap}(\mathrm{OMe})]_{3} \mathrm{~A}\right) \cdot \operatorname{poly}(\mathrm{dT})$ & 57 & & \\
$\mathrm{~d}(\mathrm{Cp}(\mathrm{OMe}) \cdot \mathrm{poly}(\mathrm{dG})$ & 45 & $\mathrm{~d}(\mathrm{Cp}(\mathrm{OMe}) \mathrm{Cp}(\mathrm{OMe}) \mathrm{C}) \cdot \operatorname{poly}(\mathrm{rG})$ & \\
$\mathrm{d}(\mathrm{Cp}(\mathrm{OMe}) \mathrm{Cp}(\mathrm{OMe}) \mathrm{C}) \cdot \operatorname{poly}(\mathrm{dG})$ & 55 & 12 \\
\hline
\end{tabular}

Table II $T_{\mathrm{m}}$ values for hybrids between methyl phosphonate and phosphate-ethylated oligonucleotides and natural DNA or RNA.

\begin{tabular}{|l|c|l|r|}
\hline System & $T_{\mathrm{m}}\left({ }^{\circ} \mathrm{C}\right)$ & System & $T_{\mathrm{m}}\left({ }^{\circ} \mathrm{C}\right)$ \\
\hline $\mathrm{d}\left([\mathrm{Tp}(\mathrm{Me})]_{8} \mathrm{~T}\right) \cdot \operatorname{poly}(\mathrm{dA})$ & $12^{\mathrm{a}}$ & $\mathrm{d}\left([\mathrm{Tp}(\mathrm{Me})]_{8} \mathrm{~T}\right) \cdot \operatorname{poly}(\mathrm{rA})$ & $<$ \\
$\mathrm{d}(\mathrm{Ap}(\mathrm{Me}) \mathrm{A}) \cdot \operatorname{poly}(\mathrm{dT})$ & 19 & $\mathrm{~d}(\mathrm{Ap}(\mathrm{Me}) \mathrm{A}) \cdot \mathrm{poly}(\mathrm{U})$ & 17 \\
$\mathrm{~d}(\mathrm{Ap}(\mathrm{Me}) \mathrm{Ap}(\mathrm{Me}) \mathrm{A}) \cdot \mathrm{poly}(\mathrm{dT})$ & 37 & $\mathrm{~d}(\mathrm{Ap}(\mathrm{Me}) \mathrm{Ap}(\mathrm{Me}) \mathrm{A}) \cdot \mathrm{poly}(\mathrm{U})$ & 33 \\
$\mathrm{~d}\left([\mathrm{Ap}(\mathrm{Me})]_{3} \mathrm{~A}\right) \cdot \operatorname{poly}(\mathrm{dT})$ & 45 & $\mathrm{~d}\left([\mathrm{Ap}(\mathrm{Me})]_{3} \mathrm{~A}\right) \cdot \operatorname{poly}(\mathrm{U})$ & 43 \\
\hline $\mathrm{d}\left([\mathrm{Tp}(\mathrm{OEt})]_{7} \mathrm{~T}\right) \cdot \operatorname{poly}(\mathrm{dA})$ & $9^{\mathrm{b}}$ & $\mathrm{d}\left(\mathrm{T}[\mathrm{p}(\mathrm{OEt})]_{7} \mathrm{~T}\right) \cdot \operatorname{poly}(\mathrm{rA})$ & $-11^{\mathrm{b}}$ \\
& & $\mathrm{d}(\mathrm{Ap}(\mathrm{OEt}) \mathrm{A}) \cdot \operatorname{poly}(\mathrm{U})$ & 12 \\
\hline
\end{tabular}

${ }^{a}$ Range from $0-25^{\circ} \mathrm{C} . \quad{ }^{\mathrm{b}}$ Temperature of $90 \%$ dissociation into single strand $\left(T_{0.9}\right)$. 


\section{Discussion}

\section{Steric factors}

It is obvious from molecular models that the various alkyl groups in the neutral DNA systems, whether directly linked to phosphorus or attached to a phosphate oxygen, cause additional steric interactions compared to natural DNA. This is most obvious when comparing duplexes with either natural DNA or natural RNA, since in the former duplex a B-type helical geometry is found, while in the latter an A conformation is required ${ }^{17}$. Steric interactions are of higher importance in a duplex with an A geometry, since intrastrand phosphate-phosphate distances are strongly diminished $^{18}$, while substituents on phosphorus are in closer contact with other parts of the DNA ${ }^{12}$. In accordance with these facts, all systems listed in Tables I and II display a stronger hybridization with DNA than with RNA. The difference in $T_{\mathrm{m}}$ value is expected to follow the steric requirements of the phosphorus substituents. The increase in steric size on going from methyl phosphonate to phosphate-methylated to phosphate-ethylated is indeed reflected in the $T_{\mathrm{m}}$ values of the adenosine dinucleotides hybridized with poly(U): d(Ap(Me)A), $17^{\circ} \mathrm{C}$; d(Ap(OMe)A $), 13^{\circ} \mathrm{C}$; $\mathrm{d}(\mathrm{Ap}(\mathrm{OEt}) \mathrm{A}), 12^{\circ} \mathrm{C}$. In these systems, no interactions between neighbouring phosphate groups are present. For trinucleotides, these become more important and cause stronger differences in $T_{\mathrm{m}}$ value: $\mathrm{d}(\mathrm{Ap}(\mathrm{Me}) \mathrm{Ap}(\mathrm{Me}) \mathrm{A})$ hybridizes with poly $(\mathrm{U})$ and has a $T_{\mathrm{m}}$ value of $33^{\circ} \mathrm{C}$, while no duplex between $\mathrm{d}(\mathrm{Ap}(\mathrm{OMe}) \mathrm{Ap}(\mathrm{OMe}) \mathrm{A})$ and poly $(\mathrm{U})$ is found above $10^{\circ} \mathrm{C}$.

Another factor that can influence steric interactions is the chirality of phosphorus which is present in all the phosphate-modified systems presented here. From a molecular model abstracted from a B DNA duplex, it follows that two orientations of the phosphorus substituents are possible, designated outwards and inwards, corresponding with the two chiral forms of the phosphorus atom. The Cahn-Ingold-Prelog R/S notation can be applied to phosphorus ${ }^{19}$, but gives a different label to spatially identical orientations of the alkyl substituent for the three systems. Model studies show that the inwards orientation can cause stronger steric repulsions, and hence a lower duplex stability is present for this phosphorus configuration. Experimental data on this effect are limited, since it requires separation of the diastereomeric forms of the neutral oligonucleotides. However, for phosphate-methylated DNA it has been found that the phosphorus configuration does not affect its ability to hybridize with natural DNA. This is most evident for the trinucleotide $\mathrm{d}(\mathrm{Ap}(\mathrm{OMe}) \mathrm{Ap}(\mathrm{OMe}) \mathrm{A})$, which consists of four diastereomeric forms. Hybridization with poly(dT) gives rise to a single sharp melting transition at $41^{\circ} \mathrm{C}$ in both UV and NMR experiments, indicating that all diastereomers form an equally stable duplex. A similar behaviour was found for all the diastereomeric mixtures shown in Table I. A more indirect proof of the similarity of the various diastereomeric forms was provided by stability studies on the parallel duplexes formed by phosphatemethylated oligothymidines (vide supra). Even for doublestranded $d\left([\mathrm{Tp}(\mathrm{OMe})]_{5} \mathrm{~T}\right)$, which contains five chiral centres in each strand, a well-defined melting transition at $65^{\circ} \mathrm{C}$ was found in both $\mathrm{UV}^{8}$ and ${ }^{1} \mathrm{H}$ NMR studies ${ }^{8 \mathrm{a}}$.

For phosphate-ethylated triester systems, a clear difference has been found for the duplex stability of oligonucleotides containing one modified phosphate with a specific chirality. The self-complementary octamer $d(G p G p A p A p(O E t)$ $\mathrm{TpTpCpC}$ ) forms a duplex with a $T_{\mathrm{m}}$ value of $31^{\circ} \mathrm{C}$ for the outwards orientation of the ethyl group and already melts at $25^{\circ} \mathrm{C}$ when an inward orientation is present ${ }^{20}$. Evidently, the large ethyl group has a much stronger effect on the duplex stability in comparison with a methyl group.

In the case of methyl phosphonate DNA, one would not expect, on the basis of steric factors, to find a difference between the two methyl orientations, since methyl is steri cally even less demanding than methoxy (vide supra). For small fragments (up to four nucleotides), this is indeed the case, however longer fragments of methyl phosphonate DNA exhibit strong variations in their hybridization ability For example, the hybrid of the decamer $d(\mathrm{Tp}(\mathrm{Me})$. $\left.[\mathrm{TpTp}(\mathrm{Me})]_{4} \mathrm{~T}\right)$, with alternating phosphate and methy] phosphonate groups and poly (dA), has a $T_{m}$ value of $34^{\circ} \mathrm{C}$ when one chirality is present and dissociates at $2^{\circ} \mathrm{C}$ for the other chirality ${ }^{\mathrm{Ib}}$. A similar behaviour is found for the hybridization of this decamer with the RNA poly(A) $T_{\mathrm{m}}=20^{\circ} \mathrm{C}$ for the outward form and $T_{\mathrm{m}}=0^{\circ} \mathrm{C}$ for the inward form. Furthermore, the nonamer $\mathrm{d}\left([\mathrm{Tp}(\mathrm{Me})]_{8} \mathrm{~T}\right.$ shows a broad range of $T_{m}$ values $\left(0-25^{\circ} \mathrm{C}\right)$ upon hybrid. zation with poly (dA).(see Table II), which demonstrates the importance of the diastereomeric composition of the oligo: mer for duplex stability ${ }^{12}$. Evidently, other influences besides steric hindrance must cause a difference between the isomers of the chiral methyl phosphonate group. An explana: tion for this behaviour can be given, on the basis of he stereoelectronic effects in phosphate and methyl phos phonate groups.

\section{Stereoelectronic factors}

The difference between the hybridization properties methyl phosphonate and phosphate-methylated DNA with natural DNA may be due to the fact that the methyl phos: phonate strands cannot readily adopt the right-hande backbone conformation which is needed for the formation
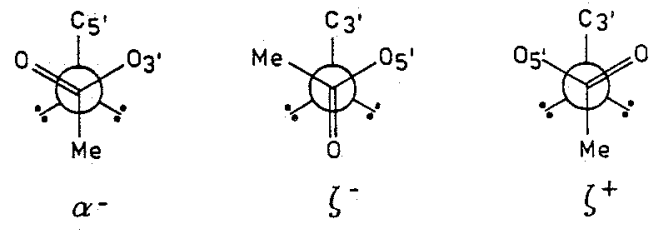

Fig. 2. Newman projections of the $\alpha^{-}$rotamer and the and $\zeta^{+}$rotamers for the methyl phosphonate group with the $S$ configuration.

of a stable duplex. In particular, this concerns the backbon angles $\zeta\left(C\left(3^{\prime}\right)-\mathrm{O}\left(3^{\prime}\right)-\mathrm{P}-\mathrm{O}\left(5^{\prime}\right)\right)$ and $\alpha\left(\mathrm{O}\left(3^{\prime}\right)-\mathrm{P}-\mathrm{O}\left(5^{\prime}\right)\right.$. $\left.-\mathrm{C}\left(5^{\prime}\right)\right)$, which must reside in the $\zeta^{-}$and $\alpha^{-}$domains for right-handed DNA ${ }^{21}$. In the case of a methyl phosphonate linkage, it can be shown that the combination $\left\{\alpha^{-}, \zeta^{-}\right\}$ energetically unfavoured. Fig. 2 depicts the Newman projec tions of the $\alpha^{-}$and $\zeta^{-}$rotamers for the $S_{\mathrm{P}}$ configuration of phosphorus. Clearly, both lone pairs on $O\left(5^{\prime}\right)$ have favourable trans orientation with respect to a phos phorus-oxygen bond ${ }^{22}$ in the $\alpha^{-}$rotamer. The $\zeta^{-}$rotame shows an undesirable trans location of the phosphorus-cat bon bond and one of the lone pairs on $O\left(3^{\prime}\right)$, which can be

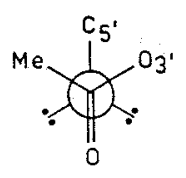

$\alpha^{-}$

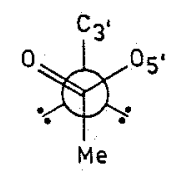

$\zeta^{-}$

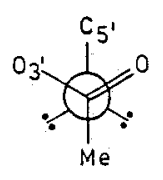

$\alpha+$
Fig. 3. Newman projections of the $\alpha^{-}$and $\alpha^{+}$rotamers and the $\zeta^{-}$rotamer for the methyl phosphonate group with the $R_{P}$ configuration. relievec the $\mathrm{Ne}$ figurati with thi $O\left(3^{\prime}\right)$ i the unf $O\left(5^{\prime}\right)$ a from $\alpha$ cannot analysi: solution mation availab phorus of the the $S_{\mathrm{P}}$ clearly realizer $\zeta^{+}$(se

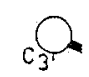

Fig. 4.

the $X-1$ $\left\{\alpha^{-}, \zeta\right.$ structu

d(Ap) ( phonat bone $g$ handec conclu may as stable For lo! hander explair tems. availal tion of phorus explan tems $\mathrm{d}([\mathrm{Ap})$ $\left(T_{\mathrm{m}} \mathrm{V}\right.$ : methy d(ApC and 4 :

Coope The $\mathrm{p}$ : oligon than $c$ systen phate. 


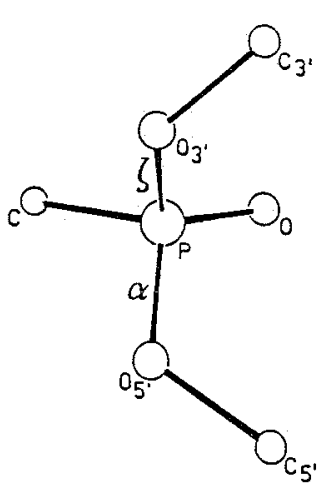

Fig. 4. Left: Standard $\left\{\alpha^{-}, \zeta^{-}\right\}$conformation as observed in the X-ray crystal structure of natural $r(A U)^{25}$. Right: Distorted $\left\{\alpha^{-}, \zeta^{+}\right\}$conformation which is found in the $X$-ray crystal structure of $d(A p(M e) T)$ with the $S_{\mathrm{p}}$ configuration ${ }^{24}$.

$\mathrm{d}(\mathrm{Ap}(\mathrm{Me}) \mathrm{T})$ strongly supports our argument that phosphonate internucleotide linkages correspond with a backbone geometry which does not intrinsically match the righthanded DNA conformation. Notwithstanding, it can be concluded that short methyl phosphonate oligonucleotides may adopt the unfavourable $\left\{\alpha^{-}, \zeta^{-}\right\}$conformation, since stable hybrids with natural DNAs are formed (vide supra). For longer strands of methyl phosphonate DNA, the righthanded backbone becomes highly unfavoured, which explains why only poor hybridization is found in these systems. In contrast, the $\left\{\alpha^{-}, \zeta^{-}\right\}$conformation is readily available for phosphate-methylated DNA, since trans location of the lone pairs on either $\mathrm{O}\left(5^{\prime}\right)$ or $\mathrm{O}\left(3^{\prime}\right)$ with a phosphorus-carbon bond is excluded. In agreement with this explanation is the fact that the phosphate-methylated systems $d(\mathrm{Ap}(\mathrm{OMe}) \mathrm{A}) . \mathrm{d}(\mathrm{Ap}(\mathrm{OMe}) \mathrm{Ap}(\mathrm{OMe}) \mathrm{A})$ and $\mathrm{d}\left([\mathrm{Ap}(\mathrm{OMe})]_{3} \mathrm{~A}\right)$ form more stable hybrids with poly(dT) $\left(T_{\mathrm{m}}\right.$ values 30,41 and $57^{\circ} \mathrm{C}$ ) than do the corresponding methyl phosphonate systems d(Ap(Me)A), $\mathrm{d}(\mathrm{Ap}(\mathrm{Me}) \mathrm{Ap}(\mathrm{Me}) \mathrm{A})$ and $\mathrm{d}\left([\mathrm{Ap}(\mathrm{Me})]_{3} \mathrm{~A}\right)\left(T_{\mathrm{m}}\right.$ values 19,37 and $45^{\circ} \mathrm{C}$ ).

\section{Cooperative effects}

The present results clearly show that phosphate-methylated oligonucleotides hybridize more strongly with natural DNA than do either methyl phosphonate or phosphate-ethylated systems. Nevertheless, it must be assumed that the phosphate-methylated strand adopts a somewhat different geometry than natural DNA, since all intrastrand phosphate-phosphate repulsions are eliminated. The situation may be similar to the complexation between DNA and histones (basic proteins), where a one-sided shielding of the phosphate charges causes a bending of the DNA duplex around the protein ${ }^{26}$.

We examined the effect of an altered geometry for the phosphate-methylated DNA on the hybridization process of the trinucleotide $\mathrm{d}(\mathrm{Ap}(\mathrm{OMe}) \mathrm{Ap}(\mathrm{OMe}) \mathrm{A})$ with natural oligoand poly $(\mathrm{dT})$. The $T_{\mathrm{m}}$ value of the hybrid was measured for various lengths of the natural strand and different degrees of occupancy. The results of these experiments (see Table III) clearly show that a certain number of phosphatemethylated trimers must be present to realize a stable duplex, suggesting a cooperative behaviour in the hybridization between phosphate-methylated and natural DNA:

Table III $T_{\mathrm{m}}$ values for hybrids between d(Ap(OMe)Ap(OMe)A) and natural oligo- and poly $(d T)$.

\begin{tabular}{|l|c|c|}
\hline System & $\begin{array}{c}\text { Base ratio } \\
(\mathrm{A} y \mathrm{~T})\end{array}$ & $T_{\mathrm{m}}\left({ }^{\circ} \mathrm{C}\right)$ \\
\hline $\mathrm{d}(\mathrm{Ap}(\mathrm{OMe}) \mathrm{Ap}(\mathrm{OMe}) \mathrm{A}) \cdot \mathrm{poly}(\mathrm{dT})$ & 1 & 41 \\
& $1 / 2$ & 39 \\
$\mathrm{~d}(\mathrm{Ap}(\mathrm{OMe}) \mathrm{Ap}(\mathrm{OMe}) \mathrm{A}) \cdot \mathrm{d}\left(\mathrm{T}_{30}\right)$ & 1 & 27 \\
& $1 / 2$ & 23 \\
$\mathrm{~d}(\mathrm{Ap}(\mathrm{OMe}) \mathrm{Ap}(\mathrm{OMe}) \mathrm{A}) \cdot \mathrm{d}\left(\mathrm{T}_{10}\right)$ & 1 & $<10$ \\
$\mathrm{~d}(\mathrm{Ap}(\mathrm{OMe}) \mathrm{Ap}(\mathrm{OMe}) \mathrm{A}) \cdot \mathrm{d}\left(\mathrm{T}_{5}\right)$ & 1 & $<10$ \\
\hline
\end{tabular}

Since the length of the natural DNA is of importance, the $T_{\mathrm{m}}$ value cannot solely be determined by the changes in enthalpy and entropy caused by base pair formation $\left(\Delta H_{n}^{0}\right.$ and $\Delta S_{n}^{0}$ for $n$ base pairs). We have therefore ${ }^{27}$ previously suggested that the natural DNA strand must adapt its conformation prior to hybridization, introducing an extra loss of entropy $\Delta S_{k}^{0 \prime}$ (for a length of $k$ nucleotides). The cooperative behaviour can be incorporated via a parameter $\alpha$, ranging from 0 to 1 , which decreases the impact of the extra entropy loss by successive multiplications (yielding $\alpha^{\mathrm{i}} \cdot \Delta S_{k}^{0^{\prime}}$ for the $i^{\text {th }}$ hybridization). On summing all contributions for $p$ phosphate-methylated $n$-mers hybridized with a natual $k$-mer, it is found that:

$$
T_{\mathrm{m}}=\frac{\Delta H_{n}^{0}}{\Delta S_{n}^{0}+\frac{1-\alpha^{p}}{p \cdot(1-\alpha)} \cdot \Delta S_{k}^{0}}
$$

Since $\Delta H_{3}^{0}$ has been previously determined ${ }^{5}$ to be -23.4 $\mathrm{kcal} / \mathrm{mol}$ for A-T base pairs, an analysis of the results in Table III in the light of this model can now be performed. It is found that the values $\alpha=0.89, \Delta S_{3}^{0}=-74.1$ $\mathrm{cal} \cdot \mathrm{mol}^{-1} \cdot \mathrm{K}^{-1}, \Delta S_{30}^{0}=-6.2 \mathrm{cal} \cdot \mathrm{mol}^{-1} \cdot \mathrm{K}^{-1}$ and $\Delta S_{\text {poly }}^{0}{ }^{\prime}=-4.4 \mathrm{cal} \cdot \mathrm{mol}^{-1} \cdot \mathrm{K}^{-1}$ are consistent with the observations, while $\Delta S_{5}^{0^{\prime}}$ and $\Delta S_{10}^{0}{ }^{\prime}$ must be lower than -8 $\mathrm{cal} \cdot \mathrm{mol}^{-1} \cdot \mathrm{K}^{-1}$.

From this model it appears that modification of the phosphates in one strand has two consequences, viz. (i) stabilization of the duplex due to elimination of electrostatic repulsions, giving a larger $\Delta H_{n}^{0}$ and (ii) destabilization of the duplex due to structural changes in the modified strand, leading to a larger total entropy change. The balance of these effects has been found to be in favour of stronger duplex formation for the results presented on phosphatemethylated/natural systems (vide supra). A similar shielding of the phosphate groups in one strand can also occur in 
protein-DNA complexes where cationic amino-acid sidechains associate with the negative phosphate groups (vide supra). In most earlier studies, proteins were chosen which simultaneously complex with both DNA strands ${ }^{28}$, so that only the stabilizing effect is present, since any structural modifications are identical in both strands. However, on extrapolating the above results on hybrids formed between phosphate-methylated and natural DNA, one would expect a different result from protein complexation with the phosphate groups in one strand only. A structural difference between the strands will occur and the enthalpy and entropy of hybridization will be different from the phosphatemethylated/natural systems, which may lead to destabilization of the DNA duplex.

In order to study whether this type of duplex destabilization can occur, we have performed thermodynamic model studies on a DNA duplex containing A-T base pairs which is complexed with protein in only one strand ${ }^{29}$. For these calculations, we adapted the model of Breslauer et al. ${ }^{30}$ for determining the enthalpy and free energy of hybridization in natural DNA duplexes. They found that summing fixed contributions $(\Delta h$ and $\Delta g$ ) for all dinucleotide units in a duplex gave correct values for these thermodynamic quantities. Using different dimer contributions, $\Delta h^{*}=\beta \cdot \Delta h$ and $\Delta g^{*}=\delta \cdot \Delta g$, for the A-T base pairs in our model duplex, and the abovementioned formula for the $T_{\mathrm{m}}$ value of shielded duplexes, we could evaluate the stability of a unilaterally protein-shielded duplex. The results of the calculations show ${ }^{29}$ that the effect of protein shielding on the duplex stability depends mainly on the ratio $\delta / \beta$. For $\delta / \beta>1$, additional stabilization of the duplex is always found, independent of the number of shielded phosphates. When $\delta / \beta<1$, an increase in the length of unilateral shielding results in a lower $T_{\mathrm{m}}$ value for the duplex.

This latter process may be of interest in understanding the action of enzymes, which can open a DNA duplex for replication or transcription. Several structural features known for these proteins coincide with our model assumptions. For enzymes which unwind the DNA duplex completely for replication (helicases), it is known that only a short stretch (ca. 8 base pairs) of the DNA is covered by the protein ${ }^{31}$. More specifically, the so-called gene 5 protein of phage fd is known to have a high affinity for a single strand of DNA and to associate primarily with 5 adjacent phosphate groups via lysine and arginine residues ${ }^{32}$. For the RNA polymerase enzymes which partially unwind a DNA duplex for transcription, it is established that $E$. coli RNA polymerase, for example, always remains associated with one of the DNA strands over a length of 14 base pairs ${ }^{33}$. For many other RNA polymerases, it has been reported that lengths of $17^{34}$ up to 70 base pairs ${ }^{35}$ of the DNA duplex are covered by the protein. Furthermore, the interaction between DNA and protein in this case is thought to be mainly electrostatic ${ }^{36}$. Our results, in good agreement with the above facts, show ${ }^{29}$ that destabilization of a DNA duplex by phosphate shielding in the interior of the sequence (as in transcription) requires a modified stretch, which is almost twice as long, compared to a similar duplex opening at the end of the sequence (as in replication of linear DNA). It therefore may be possible that unilateral protein complexation serves as an initiating step for processes which involve the dissociation of the DNA duplex.

\section{Experimental}

'H NMR spectra were recorded in the FT mode at 200,500 or $600 \mathrm{MHz}^{37}$ on Bruker spectrometers. Measurements in water refer to an $85 / 15(\mathrm{v} / \mathrm{v})$ mixture of $\mathrm{H}_{2} \mathrm{O}$ and $\mathrm{D}_{2} \mathrm{O}$, in which the deuterium provided the field-frequency lock. The strong water signal was sup. pressed using the technique described by Haasnoot et al. ${ }^{38}$. Protof chemical shifts were referenced against HDO $(\delta 4.68 \mathrm{ppm}$ ${ }^{31} \mathrm{P}$ NMR spectra were recorded in the FT mode at $80.9 \mathrm{MHz} 0$ a Bruker AC-200 spectrometer. Chemical shifts are relative $t$ $85 \% \mathrm{H}_{3} \mathrm{PO}_{4}$; they are designated positive if downfield from th standard. The UV hyperchromicity measurements were performe on a Perkin-Elmer 124 spectrophotometer using 10 -mm cuvette and a wavelength of $260 \mathrm{~nm}$. The natural oligonucleotides $d\left(T_{5}\right.$ $d\left(T_{10}\right)$ and $d\left(T_{30}\right)$ were prepared via the standard phosphoru amidite protocol ${ }^{13}$ on an Applied Biosystems 381A DN synthesizer. Purification was carried out using alcohol precipi tation $^{39}$.

\section{$d(A p(O M e) A), d(A p(O M e) A p(O M e) A)$ and $d\left([A p(O M e)]_{3} A\right)$}

Starting compound $3^{\prime}$-O-acetyl-6-N-[1-(dimethylamino)ethylidene]-2 -deoxyadenosine. $5^{\prime}-O-\left(4,4^{\prime}\right.$-Dimethoxytrityl)-6- $N-[1$-(dimethylam no)ethylidene]-2'-deoxyadenosine ${ }^{14}(5 \mathrm{mmol}, 3.2 \mathrm{~g})$ was coeva porated three times with pyridine to remove water and dissolved i $15 \mathrm{ml}$ pyridine. Acetic anhydride $(12 \mathrm{mmol}, 12.2 \mathrm{~g})$ was added an the solution was stirred overnight. Pyridine was then removed b coevaporation with water and the yellow residue was dissolved in $50 \mathrm{ml}$ chloroform. To eliminate excess acetic anhydride, this soli tion was treated with a $5 \%$ aqueous sodium bicarbonate solution and extracted with three $25 \mathrm{ml}$ portions of water. Concentration 0 the organic layer afforded a white foam, which was dissolved in $30 \mathrm{ml}$ of nitromethane/methanol $(95 / 5 \mathrm{v} / \mathrm{v})$ and treated with an hydrous zinc bromide $(31.1 \mathrm{mmol}, 7.19 \mathrm{~g}$ ) for $1 \mathrm{~h}$. To the red sol tion, $150 \mathrm{ml}$ of a $5 \%$ aqueous ammonium acetate solution wa added, followed by extraction with four portions of $50 \mathrm{ml}$ d chloromethane. The organic layer was dried over sodium sulfat and concentrated. The brown residue was purified by column chro matography on a Woelm silica gel column. Impurities were firs eluted with dichloromethane, after which the product was removed from the column using dichloromethane/methanol $(95 / 5 \mathrm{v} / \mathrm{v})$ eluent $\left(R_{\mathrm{f}} 0.16\right)$. The product was obtained as a white foam in $78^{\circ}$ yield $(2.25 \mathrm{~g})$. ${ }^{\mathrm{H}} \mathrm{H}$ NMR $\left(\mathrm{CDCl}_{3}\right): 2.11\left(3 \mathrm{H}, \mathrm{s}, \mathrm{N}=\mathrm{C}-\mathrm{CH}_{3}\right), 2$. (3H, s, $\mathrm{CH}_{3}$ acetyl), $2.42\left(1 \mathrm{H}, \mathrm{m}, \mathrm{H}\left(2^{\prime \prime}\right)\right), 3.15\left(6 \mathrm{H}, \mathrm{s}, \mathrm{N}\left(\mathrm{CH}_{3}\right)_{2}\right.$ $3.25\left(1 \mathrm{H}, \mathrm{m}, \mathrm{H}\left(2^{\prime}\right)\right), 3.94\left(2 \mathrm{H}, \mathrm{m}, \mathrm{H}\left(5^{\prime}\right) / \mathrm{H}\left(5^{\prime \prime}\right)\right), 4.27(1 \mathrm{H}$, $\left.\mathrm{H}\left(4^{\prime}\right)\right), 5.58\left(1 \mathrm{H}, \mathrm{m}, \mathrm{H}\left(3^{\prime}\right)\right), 6.30\left(1 \mathrm{H}, \mathrm{dd}, \mathrm{H}\left(1^{\prime}\right)\right), 7.98(1 \mathrm{H}$, $\mathrm{H}(2)), 8.58(1 \mathrm{H}, \mathrm{s}, \mathrm{H}(8))$.

Coupling compound $3^{\prime}-\mathrm{O}-[$ (diisopropylamino)methoxyphosphino]-5 $-\mathrm{O}-\left(4,4^{\prime}\right.$-dimethoxytrityl $)-6-\mathrm{N}-\left[1-(\right.$ dimethylamino) ethylidene $]-2^{\prime}$-de oxyadenosine ${ }^{40}$. 5'-O-(4,4' - Dimethoxytrityl $)-6-N-[1$ - (dimethy amino)-ethylidene]-2'-deoxyadenosine ${ }^{14}(19.62 \mathrm{mmol}, 12.2 \mathrm{~g})$ an diisopropylethylamine $(80 \mathrm{mmol}, 14 \mathrm{ml})$ were dissolved in $60 \mathrm{~m}$ chloroform under an argon atmosphere and chloro(diisopropy amino)methoxyphosphine ${ }^{40}(21.6 \mathrm{mmol}, 4.32 \mathrm{ml})$ was added ove $90 \mathrm{~s}$ with stirring. After $1 \mathrm{~h}$, the mixture was diluted with $500 \mathrm{ml}$ eth acetate (pre-washed with sodium bicarbonate) and washed with fou $200-\mathrm{ml}$ portions of a saturated sodium chloride solution and 75 water. The solution was dried over sodium sulfate and concentrate The resulting foam was chromatographed on a Woelm silica g column, using dichloromethane/hexane/triethylamine $(5 / 4 / 1 \mathrm{v} / \mathrm{v} / \mathrm{i})$ as eluent $\left(R_{\mathrm{f}} 0.40\right)$. The product was obtained as a yellowish foam $70 \%$ yield $(10.76 \mathrm{~g})$ and stored under argon. ${ }^{1} \mathrm{H}$ NMR $\left(\mathrm{CD}_{3} \mathrm{CN}\right.$ $\delta 1.12\left(12 \mathrm{H}, \mathrm{m}, \mathrm{CH}_{3}\right.$ isopropyl $), 2.01\left(3 \mathrm{H}, \mathrm{s}, \mathrm{N}=\mathrm{C}-\mathrm{CH}_{3}\right), 2.53(1 \mathrm{H}$ $\left.\mathrm{m}, \mathrm{H}\left(2^{\prime \prime}\right)\right), 3.01\left(1 \mathrm{H}, \mathrm{m}, \mathrm{H}\left(2^{\prime}\right)\right), 3.10\left(12 \mathrm{H}, \mathrm{s}, \mathrm{N}\left(\mathrm{CH}_{3}\right)_{2}\right), 3.29(2 \mathrm{H}$, $\left.\mathrm{H}\left(5^{\prime}\right) / \mathrm{H}\left(5^{\prime \prime}\right)\right), 3.26\left(3 \mathrm{H}, \mathrm{d}, \mathrm{POCH}_{3}, J 13.2 \mathrm{~Hz}\right), 3.36(3 \mathrm{H}, \mathrm{d}, \mathrm{POCH}$ $J 13.2 \mathrm{~Hz}), 3.55(2 \mathrm{H}, \mathrm{m}, \mathrm{H}$ isopropyl $), 3.73\left(6 \mathrm{H}, \mathrm{s}, \mathrm{OCH}_{3}\right), 4.17(1 \mathrm{H}$ $\left.\mathrm{m}, \mathrm{H}\left(4^{\prime}\right)\right), 4.83\left(1 \mathrm{H}, \mathrm{m}, \mathrm{H}\left(3^{\prime}\right)\right), 6.38\left(1 \mathrm{H}, \mathrm{dd}, \mathrm{H}\left(1^{\prime}\right)\right), 6.73-7.40(13 \mathrm{H}$ $\mathrm{m}$, trityl $), 8.05(1 \mathrm{H}, \mathrm{s}, \mathrm{H}(2)), 8.37(1 \mathrm{H}, \mathrm{s}, \mathrm{H}(8)) .{ }^{31} \mathrm{P}$ NMR $\left(\mathrm{CD}_{3} \mathrm{CN}\right)$ 154.40 and 154.66

Coupling reaction, oxidation and detritylation to form $3^{\prime}-\mathrm{O}-$ acetyl-6- $\mathrm{-}$ -[1-(dimethylamino)ethylidene $]-2^{\prime}$-deoxyadenosine- $5^{\prime}$ - 6-N- $[1$-(dime thylamino)ethylidene $/ 2^{\prime}$-deoxyadenosine $-3^{\prime}$ methyl phosphate ${ }^{13}$. Th starting compound $3^{\prime}-\mathrm{O}$-acetyl-6- $\mathrm{N}$-[1-(dimethylamino)ethylidene -2 -deoxyadenosine ( $1 \mathrm{mmol}, 0.36 \mathrm{~g}$ ) and the coupling compoun ( $1 \mathrm{mmol}, 0.78 \mathrm{~g}$ ) were each coevaporated three times with pyridine and then dissolved in pyridine. To initiate the reaction, $1 H$-tetri zole $(5 \mathrm{mmol}, 0.35 \mathrm{~g})$ was added. The solution was then stirred fo $2 \mathrm{~h}$ and concentrated. ${ }^{31} \mathrm{P}$ NMR $\left(\mathrm{CD}_{3} \mathrm{CN}\right): \delta 146.13$ and 145.91 (ratio 1.08:1).

The phosphite was then oxidized by addition of a solution of iodin $(1 \mathrm{mmol}, 0.26 \mathrm{~g})$ in acetonitrile/lutidine/water $(3 / 2 / 1 \mathrm{v} / \mathrm{v} / \mathrm{v})$. Afte
$5 \mathrm{~min}$ and ex solutior centrat Woelm $v / v)$ as (CDCl: The pr. $v(v)$ an then a tration yield $\left(\mathrm{CD}_{3} \mathrm{O}\right.$ $d(A p)$ 
$5 \mathrm{~min}$, the brown solution was diluted with $100 \mathrm{ml}$ ethyl acetate and extracted with $20 \mathrm{ml}$ of a $1 \%$ aqueous sodium bisulfate solution. The organic layer was dried over sodium sulfate and concentrated. The resulting viscous oil was chromatographed on a Woelm silica gel column, using dichloromethane/methanol $(90 / 10$ $\mathrm{v} / \mathrm{v})$ as eluent $\left(R_{\mathrm{f}} 0.40\right)$. The yield was $30 \%(0.32 \mathrm{~g}) .{ }^{31} \mathrm{P}$ NMR $\left(\mathrm{CDCl}_{3}\right): \delta 0.05$ and -0.33 (ratio $1.09: 1$ ).

The product was then dissolved in $10 \mathrm{ml}$ of acetic acid/water $(4 / 1$ $v / \mathrm{v}$ ) and the solution heated to $50^{\circ} \mathrm{C}$ for $2 \mathrm{~h} ; 25 \mathrm{ml}$ cold water was $v / v)$ anded to precipitate the $4,4^{\prime}$-dimethoxytrityl alcohol. Filthation and coevaporation with water yielded the dinucleotide in a yield of $81 \%(0.18 \mathrm{~g}) \cdot R_{\mathrm{f}}\left(\mathrm{CH}_{2} \mathrm{Cl}_{2} / \mathrm{CH}_{3} \mathrm{OH}\right) \quad 0.26$. ${ }^{31} \mathrm{P} \mathrm{NMR}$ $\left(\mathrm{CD}_{3} \mathrm{OD}\right): \delta 3.34$ and 3.29 .

\section{$d($ Ap $(O M e) A)$}

The final acetylation of the $5^{\prime}$-hydroxyl group was performed as described for the starting compound. The $\mathrm{N}(6)$-protecting groups were then removed ${ }^{14}$ by dissolving the material at $40^{\circ} \mathrm{C}$ in 1,2-ethanediamine/phenol/water $(2 / 8 / 1 \mathrm{v} / \mathrm{w} / \mathrm{v})$. After $1 \mathrm{~h}$, the mixture was coevaporated with water and the product isolated using two-dimensional preparative thin-layer chromatography: $R_{\mathrm{f}} 0.23$ (eluent dichloromethane/methanol $70 / 30 \mathrm{v} / \mathrm{v})$. ' $\mathrm{H}$ NMR $\left(\mathrm{D}_{2} \mathrm{O}\right)$ : $\delta 2.08\left(3 \mathrm{H}, \mathrm{s}, \mathrm{CH}_{3}\right.$ acetyl $), 2.12\left(3 \mathrm{H}, \mathrm{s}, \mathrm{CH}_{3}\right.$ acetyl $), 2.33(1 \mathrm{H}, \mathrm{m}$, $\mathrm{H}\left(2^{\prime \prime}\right)$ of dAp $), 2.44\left(1 \mathrm{H}, \mathrm{m}, \mathrm{H}\left(2^{\prime}\right)\right.$ of dAp $), 2.62\left(1 \mathrm{H}, \mathrm{m}, \mathrm{H}\left(2^{\prime \prime}\right)\right.$ of pdA), $2.84\left(1 \mathrm{H}, \mathrm{m}, \mathrm{H}\left(2^{\prime}\right)\right.$ of pdA), $3.49\left(2 \mathrm{H}, \mathrm{m}, \mathrm{H}\left(5^{\prime}\right) / \mathrm{H}\left(5^{\prime \prime}\right)\right.$ of dAp), $3.76\left(3 \mathrm{H}, \mathrm{d}, \mathrm{POCH}_{3}, J 11.4 \mathrm{~Hz}\right), 4.22\left(1 \mathrm{H}, \mathrm{m}, \mathrm{H}\left(4^{\prime}\right)\right.$ of dAp), $4.39\left(3 \mathrm{H}, \mathrm{m}, \mathrm{H}\left(4^{\prime}\right) / \mathrm{H}\left(5^{\prime}\right) / \mathrm{H}\left(5^{\prime \prime}\right)\right.$ of pdA $), 5.00\left(1 \mathrm{H}, \mathrm{H}\left(3^{\prime}\right)\right.$ of dAp), $5.45\left(1 \mathrm{H}, \mathrm{m}, \mathrm{H}\left(3^{\prime}\right)\right.$ of pdA $), 6.03\left(1 \mathrm{H}, \mathrm{dd}, \mathrm{H}\left(1^{\prime}\right)\right.$ of dAp $), 6.26(1 \mathrm{H}$, dd, $\mathrm{H}\left(1^{\prime}\right)$ of pdA), $7.88(1 \mathrm{H}, \mathrm{s}, \mathrm{H}(2)$ of dAp), $7.96(1 \mathrm{H}, \mathrm{s}, \mathrm{H}(2)$ of pdA), $8.02(1 \mathrm{H}, \mathrm{s}, \mathrm{H}(8)$ of dAp), $8.12(1 \mathrm{H}, \mathrm{s}, \mathrm{H}(8)$ of pdA). ${ }^{31} \mathrm{P} N \mathrm{NMR}\left(\mathrm{D}_{2} \mathrm{O}\right): \delta 1.62$ and 1.72. UV: $\lambda_{\max } 257 \mathrm{~nm}, \mathrm{~A}_{250} / \mathrm{A}_{260}$ $0.83, \mathrm{~A}_{280} / \mathrm{A}_{260} 0.10$.

\section{$d(A p(O M e) A p(O M e) A)$}

The sequence of coupling with the amidite, oxidation and detritylation was repeated to add another residue. Coupling gave: ${ }^{31}$ P NMR $\left(\mathrm{CD}_{3} \mathrm{CN}\right): \delta 146.34$ and 145.68 (ratio 1.17:1) for the phosphite linkage. Oxidation: ${ }^{31} \mathrm{P} \mathrm{NMR}\left(\mathrm{CD}_{3} \mathrm{CN}\right): \delta 4.43$ and 4.33 . After detritylation, the free 5 '-hydroxyl group was acetylated as described for the starting compound. The N(6)-protecting groups were then removed using the procedure described for the dinucleotide. The product was isolated using two-dimensional preparative thin-layer chromatography, with dichloromethane/methanol (70/30 v/v) as eluent $\left(R_{\mathrm{f}} 0.12\right) .{ }^{31} \mathrm{P}$ NMR $\left(\mathrm{D}_{2} \mathrm{O}\right): \delta 3.87$. UV: $\lambda_{\max } 257 \mathrm{~nm}$, $\mathrm{A}_{250} / \mathrm{A}_{260}$ 0.94. $\mathrm{A}_{280} / \mathrm{A}_{260} 0.12$. The ${ }^{1} \mathrm{H}$ NMR spectrum is too crowded to allow a complete assignment.

\section{$d\left([\mathrm{Ap}(\mathrm{OMe})]_{3} \mathrm{~A}\right)$}

After another coupling protocol, the tetranucleotide was obtained using two-dimensional thin layer chromatography in a minute quantity, with the result that no NMR data are available $\left(R_{\mathrm{f}} 0.07\right.$, eluent dichloromethane $/$ methanol $70 / 30 \mathrm{v} / \mathrm{v}$ ). UV: $\lambda_{\max } 260 \mathrm{~nm}$, $A_{250} / A_{260} 0.83, A_{280} / A_{260} 0.16$.

\section{$d(C p(O M e) C)$ and $d(C p(O M e) C p(O M e) C)$}

4-N-[(9-Fluorenyl)methoxycarbonyl]-2'-deoxycytidine. 2'-Deoxycytidine $(4.54 \mathrm{~g}, 20 \mathrm{mmol})$ was dried by coevaporation with dry pyridine and subsequently suspended in $100 \mathrm{ml}$ of dry pyridine. $13.0 \mathrm{ml}(100 \mathrm{mmol})$ of trimethylchlorosilane was added dropwise and the mixture was stirred for $15 \mathrm{~min}^{4} .5 .8 \mathrm{~g}(22 \mathrm{mmol})$ of (9-fiuorenyl)methoxycarbonyl chloride was then added and the reaction mixture was stirred for $2 \mathrm{~h}$ at room temperature, yielding a white suspension in the yellow solution. Hydrolysis of the trimethylsilyl groups and unreacted chlorides was effected by addition of $20 \mathrm{ml}$ water. After stirring for $15 \mathrm{~min}$, a clear yellow solution was obtained, which was evaporated to near dryness by coevaporation with toluene. Upon addition of $300 \mathrm{ml}$ water to the resulting oil, a white precipitated appeared. The mixture was shaken vigorously until no more yellow oil was visible. After addition of $150 \mathrm{ml}$ of ethyl acetate and shaking, a precipitate formed on the separation layer, which was isolated by filtration and washed with ethyl acetate. Arter drying in vacuo, the product was obtained as a white solid $\left(8.71 \mathrm{~g}, 97 \%\right.$ ). ${ }^{1} \mathrm{H}$ NMR (acetone$\left.d_{6}\right): \delta 2.40\left(1 \mathrm{H}, \mathrm{m}, \mathrm{H}\left(2^{\prime}\right)\right), 2.59\left(1 \mathrm{H}, \mathrm{m}, \mathrm{H}\left(2^{\prime \prime}\right)\right), 3.77(2 \mathrm{H}, \mathrm{m}$, $\left.\mathrm{H}\left(5^{\prime}\right) / \mathrm{H}\left(5^{\prime \prime}\right)\right), 4.03\left(1 \mathrm{H}, \mathrm{m}, \mathrm{H}\left(4^{\prime}\right)\right), 4.33(1 \mathrm{H}, \mathrm{t}, \mathrm{CH}$ Fmoc $), 4.49$
(3H, m, H(3 $\left.3^{\prime}\right) / \mathrm{CH}_{2}$ Fmoc), $6.23\left(1 \mathrm{H}, \mathrm{t}, \mathrm{H}\left(1^{\prime}\right)\right), 7.12(1 \mathrm{H}, \mathrm{d}, \mathrm{H}(5))$, 7.37 (4H, m, aromatic Fmoc), $7.85(4 \mathrm{H}, \mathrm{m}$, aromatic Fmoc), 8.50 $(1 \mathrm{H}, \mathrm{d}, \mathrm{H}(6))$.

$5^{\prime}-\mathrm{O}-(4-$ Methoxytrityl)-4-N-/(9-fluorenyl)methoxycarbonyl]-2'-deoxycytidine. Base-protected $2^{\prime}$-deoxycytidine $(8.55 \mathrm{~g}, 19 \mathrm{mmol})$ was dried by coevaporation with dry pyridine and subsequently suspended in $200 \mathrm{ml}$ of dry pyridine. After addition of $6.5 \mathrm{~g}(21 \mathrm{mmol})$ of 4-methoxytrityl chloride, the solution was stirred for $15 \mathrm{~h}$. The mixture was then poured into a saturated aqueous sodium bicarbonate solution $(250 \mathrm{ml})$ and extracted three times with dichloromethane. The combined organic layers were washed with a saturated aqueous sodium bicarbonate solution and dried over magnesium sulfate. After filtration, the solution was concentrated in vacuo. Removal of all pyridine from the brownish oil was accomplished by coevaporation with toluene (twice) and 2-butanone. The resulting brown foam was purified by column chromatography on Woelm silica gel using 2-butanone as eluent $\left(R_{\mathrm{f}} 0.37\right)$, yielding $8.90 \mathrm{~g}(65 \%)$ white solid product. ${ }^{1} \mathrm{H}$ NMR $\left(\mathrm{CDCl}_{3}\right): \delta 2.25(1 \mathrm{H}$, $\left.\mathrm{m}, \mathrm{H}\left(2^{\prime}\right)\right), 2.71\left(1 \mathrm{H}, \mathrm{m}, \mathrm{H}\left(2^{\prime \prime}\right)\right), 3.47\left(2 \mathrm{H}, \mathrm{m}, \mathrm{H}\left(5^{\prime}\right) / \mathrm{H}\left(5^{\prime \prime}\right)\right), 3.79$ $\left(3 \mathrm{H}, \mathrm{s}, \mathrm{OCH}_{3}\right.$ trityl $), 4.14\left(1 \mathrm{H}, \mathrm{m}, \mathrm{H}\left(4^{\prime}\right)\right), 4.29(1 \mathrm{H}, \mathrm{t}, \mathrm{CH}$ Fmoc $)$, $4.50\left(3 \mathrm{H}, \mathrm{m}, \mathrm{H}\left(3^{\prime}\right) / \mathrm{CH}_{2} \mathrm{Fmoc}\right), 6.28\left(1 \mathrm{H}, \mathrm{t}, \mathrm{H}\left(1^{\prime}\right)\right), 6.85(2 \mathrm{H}, \mathrm{m}$, trityl), $6.99(1 \mathrm{H}, \mathrm{d}, \mathrm{H}(5)), 7.31(12 \mathrm{H}, \mathrm{m}$, trityl $), 7.41(4 \mathrm{H}, \mathrm{m}$, aromatic Fmoc), $7.69(4 \mathrm{H}, \mathrm{m}$, aromatic Fmoc), $8.22(1 \mathrm{H}, \mathrm{d}, \mathrm{H}(6))$.

Starting compound 3 '-O-acetyl-4-N-[(9-fluorenyl)methoxycarbonyl]$-2^{\prime}$-deoxycytidine. The $5^{\prime}$-tritylated, base-protected 2'-deoxycytidine $(5.00 \mathrm{~g}, 7 \mathrm{mmol})$ was stirred for $15 \mathrm{~min}$ in a mixture of $50 \mathrm{ml}$ of dry pyridine and $5 \mathrm{ml}$ of acetic anhydride. The mixture was then poured into $50 \mathrm{ml}$ of a saturated aqueous sodium bicarbonate solution and extracted twice with dichloromethane. The combined organic layers were dried over magnesium sulfate. After filtration, the solution was concentrated in vacuo. The resulting oil was purified by column chromatography on Woelm silica gel using 2-butanone as eluent $\left(R_{\mathrm{f}} 0.65\right)$, yielding a white solid. This was stirred for $15 \mathrm{~h}$ in a mixture of $160 \mathrm{ml}$ acetic acid and $40 \mathrm{ml}$ water. After addition of a further $120 \mathrm{ml}$ water, the reaction mixture was concentrated in vacuo to near dryness. The excess acetic acid and water were removed by coevaporation with 2-butanone. Crystallization from 2-butanone yielded the product as a white solid $(2.04 \mathrm{~g}, 57 \%) .{ }^{1} \mathrm{H}$ NMR $\left(\mathrm{CDCl}_{3} / \mathrm{CH}_{3} \mathrm{OD} 9 / 1 \mathrm{v} / \mathrm{v}\right): \delta 2.12(3 \mathrm{H}, \mathrm{s}$, $\mathrm{CH}_{3}$ acetyl $), 2.27\left(1 \mathrm{H}, \mathrm{m}, \mathrm{H}\left(2^{\prime}\right)\right), 2.66\left(1 \mathrm{H}, \mathrm{m}, \mathrm{H}\left(2^{\prime \prime}\right)\right), 3.86(2 \mathrm{H}, \mathrm{m}$, $\left.\mathrm{H}\left(5^{\prime}\right) / \mathrm{H}\left(5^{\prime \prime}\right)\right), 4.20\left(1 \mathrm{H}, \mathrm{m}, \mathrm{H}\left(4^{\prime}\right)\right), 4.31(1 \mathrm{H}, \mathrm{t}, \mathrm{CH}$ Fmoc $), 4.55$ (2H, d, $\mathrm{CH}_{2}$ Fmoc), $5.33\left(1 \mathrm{H}, \mathrm{m}, \mathrm{H}\left(3^{\prime}\right)\right), 6.29\left(1 \mathrm{H}, \mathrm{t}, \mathrm{H}\left(1^{\prime}\right)\right), 7.36$ ( $5 \mathrm{H}$, m, H(5)/aromatic Fmoc), $7.74(4 \mathrm{H}, \mathrm{m}$, aromatic Fmoc), 8.39 $(1 \mathrm{H}, \mathrm{d}, \mathrm{H}(6))$.

Bis(diisopropylamino)methoxyphosphine. $139.8 \mathrm{~g}$ (1.02 mol) phosphorus trichloride was cooled to $-8^{\circ} \mathrm{C}$ and $32.53 \mathrm{~g}(1.02 \mathrm{~mol})$ dry methanol was added dropwise over $1 \mathrm{~h}$ with stirring. The hydrochloric acid produced was absorbed in a gas trap containing water. Pure methoxydichlorophosphine was obtained by distillation at $100 \mathrm{mmHg}$ (b.p. $\left.35^{\circ} \mathrm{C}\right) .{ }^{31} \mathrm{P} N M R\left(\mathrm{CDCl}_{3}\right): \delta 181.5$. A solution of diisopropylamine $(162.1 \mathrm{~g}, 1.6 \mathrm{~mol})$ in $500 \mathrm{ml}$ dry diethyl ether was cooled to $0^{\circ} \mathrm{C}$ and a solution of methoxydichlorophosphine $(53.37 \mathrm{~g}, 0.4 \mathrm{~mol})$ in $20 \mathrm{ml}$ dry diethyl ether was added dropwise over $1 \mathrm{~h}$. The ammonium salt was then removed by filtration and the solution was concentrated in vacuo. Pure bis(diisopropylamino)methoxyphosphine was obtained by distillation of the residue at $1 \mathrm{mmHg}$ (b.p. $115^{\circ} \mathrm{C}$ ) in a yield of $20.9 \mathrm{~g}(20 \%)$. ${ }^{1} \mathrm{H} \mathrm{NMR}\left(\mathrm{CDCl}_{3}\right): \delta 1.20\left(24 \mathrm{H}, \mathrm{m}, \mathrm{CH}_{3}\right), 3.35\left(3 \mathrm{H}, \mathrm{d}, \mathrm{POCH}_{3}, J\right.$ $11.2 \mathrm{~Hz}), 3.52(4 \mathrm{H}, \mathrm{m}, \mathrm{CH}) .{ }^{31} \mathrm{P}$ NMR $\left(\mathrm{CDCl}_{3}\right): \delta 131.7$.

Coupling reaction, oxidation and detritylation to form $3^{\prime}-\mathrm{O}-$ acetyl-4-N$-\left[(9\right.$-fluorenyl)methoxycarbonyl $]-2^{\prime}$-deoxycytidine-5' $4-\mathrm{N}-[(9-$ fluorenyl)methoxycarbonyl]-2'-deoxycytidine-3' methyl phosphate. $2.00 \mathrm{~g}$ $(2.8 \mathrm{mmol})$ of $5^{\prime}$-tritylated, base-protected $2^{\prime}$-deoxycytidine was dried by coevaporation with dry pyridine and subsequently dissolved in $20 \mathrm{ml}$ of dry pyridine. $0.10 \mathrm{~g}(1.4 \mathrm{mmol})$ of $1 \mathrm{H}$-tetrazole and $0.86 \mathrm{~g}(3.3 \mathrm{mmol})$ bis(diisopropylamino)methoxyphosphine (dried by coevaporation with dry pyridine) were added and the reaction mixture was stirred at room temperature for $15 \mathrm{~min}$. Formation of the phosphoramidite coupling compound in situ was evident from the ${ }^{31} \mathrm{P}$ NMR spectrum $\left(\mathrm{CDCl}_{3}: \delta 149.5\right.$ and 150.2$)$. $1.65 \mathrm{~g}(3.4 \mathrm{mmol})$ of the starting compound 3'-O-acetyl-4- $N$-[(9-fluorenyl)methoxycarbonyl]-2'-deoxycytidine and $0.50 \mathrm{~g}(7 \mathrm{mmol})$ $1 H$-tetrazole (both dried by coevaporation with dry pyridine) were then added and the reaction mixture was stirred at room temperature for a further $2 \mathrm{~h}$. The phosphite $\left[{ }^{31} \mathrm{P} \mathrm{NMR}\left(\mathrm{CDCl}_{3}\right): \delta 140.4\right.$ 
and 140.8$]$ thus obtained was oxidized by addition of $1.5 \mathrm{ml}$ of tert-butyl hydroperoxide ${ }^{42}$ to give the phosphate $\left[{ }^{31} \mathrm{P}\right.$ NMR $\left(\mathrm{CDCl}_{3}\right):-0.33$ and -0.44$]$. After stirring for $5 \mathrm{~min}$, the mixture was concentrated in vacuo to near dryness and coevaporated twice with toluene and 2-butanone. The product was ditritylated by addition of a mixture of $100 \mathrm{ml}$ acetic acid and $25 \mathrm{ml}$ water. After stirring for $15 \mathrm{~h}$, a further $75 \mathrm{ml}$ water was added and the mixture was concentrated in vacuo to near dryness. The excess acetic acid and water were removed by coevaporation with 2-butanone and ethyl acetate. The product was purified by column chromatography on Woelm silica gel. The impurities were first eluted with ethyl acetate/dichloromethane $(9 / 1 \mathrm{v} / \mathrm{v})$; then the product was obtained using ethyl acetate/dichloromethane/ethanol $(85 / 10 / 5 \mathrm{v} / \mathrm{v} / \mathrm{v})$ as eluent $\left(R_{\mathrm{f}} 0.25\right)$ with a yield of $1.25 \mathrm{~g}(44 \%) .{ }^{1} \mathrm{H} \mathrm{NMR}\left(\mathrm{CDCl}_{3}\right): \delta$ $2.10\left(3 \mathrm{H}, \mathrm{s}, \mathrm{CH}_{3}\right.$ acetyl $), 2.43\left(2 \mathrm{H}, \mathrm{m}, \mathrm{H}\left(2^{\prime}\right)\right.$ of $\mathrm{dCp}$ and $\left.\mathrm{pdC}\right) .2 .77$ $\left(2 \mathrm{H}, \mathrm{m}, \mathrm{H}\left(2^{\prime \prime}\right)\right.$ of dCp and pdC), $3.84\left(3 \mathrm{H}, \mathrm{d}, \mathrm{POCH}_{3}, J 11.0 \mathrm{~Hz}\right)$, $3.91\left(2 \mathrm{H}, \mathrm{m}, \mathrm{H}\left(5^{\prime}\right) / \mathrm{H}\left(5^{\prime \prime}\right)\right.$ of $\left.\mathrm{dCp}\right)$. $4.2-4.5\left(10 \mathrm{H}, \mathrm{m}, \mathrm{H}\left(4^{\prime}\right)\right.$ of $\mathrm{dCp} / \mathrm{H}\left(4^{\prime}\right) / \mathrm{H}\left(5^{\prime}\right) / \mathrm{H}\left(5^{\prime \prime}\right)$ of $\left.\mathrm{pdC} / \mathrm{CH} / \mathrm{CH}_{2} \mathrm{Fmoc}\right), 5.29$ (2H, m, H(3') of dCp and pdC), $6.24\left(2 \mathrm{H}, \mathrm{m}, \mathrm{H}\left(1^{\prime}\right)\right.$ of $\mathrm{dCp}$ and $\left.\mathrm{pdC}\right), 7.30(10 \mathrm{H}$, $\mathrm{m}, \mathrm{H}(5)$ of $\mathrm{dCp}$ and pdC/aromatic Fmoc), $7.53(4 \mathrm{H}, \mathrm{m}$, aromatic Fmoc), 7.77 (4H, m, aromatic Fmoc), $8.07(1 \mathrm{H}, \mathrm{d}, \mathrm{H}(6)$ of $\mathrm{dCp}$ ), $8.20(1 \mathrm{H}, \mathrm{d}, \mathrm{H}(6)$ of $\mathrm{pdC}) .{ }^{31} \mathrm{P} \mathrm{NMR}\left(\mathrm{CDCl}_{3}\right): \delta-0.35$ and $0.07 \mathrm{ppm}$.

\section{$d(\mathrm{Cp}(\mathrm{OMe}) \mathrm{C})$}

The base-protecting Fmoc groups were removed ${ }^{15 b}$ by treatment with a mixture of triethylamine $(20 \mathrm{mmol} / \mathrm{mmol} \mathrm{Fmoc})$ and of pyridine $(10 \mathrm{ml} / \mathrm{mmol}$ Fmoc). After ca. $3 \mathrm{~h}$, thin-layer chromatography showed the reaction to be complete. The reaction mixture was concentrated in vacuo and the excess pyridine and triethylamine were removed by coevaporating three times with toluene. Extraction of an aqueous solution of the residue with dichloromethane removed virtually all the split-off fluorene groups. ${ }^{1} \mathrm{H}$ NMR $\left(\mathrm{D}_{2} \mathrm{O}\right): \delta 2.06\left(3 \mathrm{H}, \mathrm{s}, \mathrm{CH}_{3}\right.$ acetyl $), 2.30\left(2 \mathrm{H}, \mathrm{m}, \mathrm{H}\left(2^{\prime}\right)\right.$ of $\mathrm{dCp}$ and $\mathrm{pdC}), 2.56\left(2 \mathrm{H}, \mathrm{m}, \mathrm{H}\left(2^{\prime \prime}\right)\right.$ of $\mathrm{dCp}$ and $\left.\mathrm{pdC}\right), 3.70(2 \mathrm{H}, \mathrm{m}$, $\mathrm{H}\left(5^{\prime}\right) / \mathrm{H}\left(5^{\prime \prime}\right)$ of $\left.\mathrm{dCp}\right), 3.78\left(3 \mathrm{H}, \mathrm{d}, \mathrm{POCH}_{3}, J 11.4 \mathrm{~Hz}\right), 4.20(1 \mathrm{H}, \mathrm{m}$, $\mathrm{H}\left(4^{\prime}\right)$ of dCp $), 4.32\left(3 \mathrm{H}, \mathrm{m}, \mathrm{H}\left(4^{\prime}\right) / \mathrm{H}\left(5^{\prime}\right) / \mathrm{H}\left(5^{\prime \prime}\right)\right.$ of $\left.\mathrm{pdC}\right), 4.96(1 \mathrm{H}$, $\mathrm{m}, \mathrm{H}\left(3^{\prime}\right)$ of dCp $), 5.28\left(1 \mathrm{H}, \mathrm{m}, \mathrm{H}\left(3^{\prime}\right)\right.$ of $\left.\mathrm{pdC}\right), 5.98(1 \mathrm{H}, \mathrm{d}, \mathrm{H}(5)$ of dCp), $5.99\left(1 \mathrm{H}, \mathrm{d}, \mathrm{H}(5)\right.$ of pdC), $6.15\left(1 \mathrm{H}, \mathrm{dd}, \mathrm{H}\left(\mathrm{I}^{\prime}\right)\right.$ of $\left.\mathrm{dCp}\right), 6.18$ $\left(1 \mathrm{H}, \mathrm{dd}, \mathrm{H}\left(1^{\prime}\right)\right.$ of pdC), $7.69(1 \mathrm{H}, \mathrm{d}, \mathrm{H}(6)$ of $\mathrm{dCp}), 7.73(1 \mathrm{H}, \mathrm{d}$, $\mathrm{H}(6)$ of pdC), ${ }^{31} \mathrm{P}$ NMR $\left(\mathrm{D}_{2} \mathrm{O}\right): 1.96\left(\mathrm{~S}_{\mathrm{P}}\right)$ and $2.07\left(\mathrm{R}_{\mathrm{P}}\right)$.

\section{$d(\mathrm{Cp}(\mathrm{OMe}) \mathrm{Cp}(\mathrm{OMe}) \mathrm{C})$}

The sequence of coupling with the amidite, oxidation and detritylation was repeated to add another residue. Coupling gave: ${ }^{31} \mathrm{P}$ NMR $\left(\mathrm{CDCl}_{3}\right): \delta 140.7,0.65$ and -0.40 . Oxidation: ${ }^{31} \mathrm{P}$ NMR $\left(\mathrm{CDCl}_{3}\right): \delta-0.02,-0.05,-1.00$ and -2.00 . After detritylation, the product was purified by column chromatography on Woelm silica gel using chloroform/methanol $(9 / 1 \mathrm{v} / \mathrm{v})$ as eluent $\left(R_{f} 0.11\right)$. ${ }^{31} \mathrm{P} \mathrm{NMR}\left(\mathrm{CDCl}_{3}\right): \delta-0.13$ and -0.27 . The base-protecting Fmoc groups were removed by treatment with pyridine and triethylamine ${ }^{15 b}$. Evaporation of the pyridine yielded a crude product, which was purified by extraction of an aqueous solution with dichloromethane. The ${ }^{1} \mathrm{H}$ NMR spectrum was too crowded to allow complete assignment. ${ }^{31} \mathrm{P}$ NMR $\left(\mathrm{D}_{2} \mathrm{O}\right): \delta 1.9-2.3$ and 3.2 . $\mathrm{UV}: \lambda_{\operatorname{miax}} 268 \mathrm{~nm}, \mathrm{~A}_{250} / \mathrm{A}_{270} 0.76, \mathrm{~A}_{290} / \mathrm{A}_{270} 0.26$.

\section{Acknowledgements}

This investigation was supported in part by the Netherlands Foundation for Chemical Research (SON) with financial aid from the Netherlands Organization for Scientific Research (NWO).

\section{References}

${ }^{\text {la }}$ L. H. Koole, E. J. Lanters and H. M. Buck, J. Am. Chem. Soc. 106, 5451 (1984);

${ }^{b}$ P. S. Miller, N. Dreon, S. M. Pulford and K. B. McParland, J. Biol. Chem. 255, 9659 (1980);

${ }^{c} J$.W. Sugas and D. A. Taylor, Nucleic Acids Res. 13, 5707 (1985).
${ }^{2 a}$ P. A. Bartlett and F. Eckstein, J. Biol. Chem. 257, 8879 (1982) 2215 . W

${ }^{\mathrm{b}}$ R. Jarvest, G. Lowe, J. Baraniak and W. J. Stec, Biochem. J. 203 461 (1982);

'P. A. Usher, D. J. Richardson and F. Eckstein, Nature (London 228, 663 (1970);

${ }^{\mathrm{d}}$ R. S. Brody, S. Adler, P. Modrich, W. J. Stec, Z.J. Lesnikow. and P.A. Frey, Biochemistry 21, 2570 (1982).

${ }^{3 a}$ P. S. Miller, K. N. Fang, N. S. Kondo and P.O.P.Ts'o, J. A Chem. Soc. 93, 6657 (1971);

${ }^{b}$ P. S. Miller, K. B. McParland, K. Jayaraman and P. O. P. T Biochemistry 20, 1874 (1980).

${ }^{4}$ P. S. Miller, L. T. Braiterman and P. O. P. Ts'o, Biochemist 16, 1988 (1977).

5 L. H. Koole, M. H. P. van Genderen, R. G. Reiniers and H. Buck, Proc. K. Ned. Akad. Wet., Ser. B 90, 41 (1987) (comm nicated by $H . M$. Buck at the meeting of Dec 15,1986 ).

${ }^{6 a} H$. Weintraub, J. G. Izant and $R$. M. Hartland, Trends Genet. $22(1985)$;

${ }^{\mathrm{b}} M$. Lemaitre, B. Bayard and B. Lebleu, Proc. Natl. Acad. USA 84, 648 (1987);

' P. S. Miller, C. H. Agris, K. R. Blake, A. Murakami, S. A. Spi P.M. Reddy and P. O.P.TS'o in "Nucleic Acids, The Vectors Life", B. Pullman and J. Jortner, eds., Reidel Publishi Company, Boston, 1983, pp. 521-535.

7 L. H. Koole, P.J.L.M. Quaedflieg, W. H. A Kuijpon 33a D. C.

N. L. H. L. Broeders, H. A. Langermans, M. H. P. van Genderert ${ }^{\circ}$ W. F. and H.M. Buck, Proc. K. Ned. Akad. Wet., Ser. B 91, 20 (1988) (communicated by H.M. Buck at the meeting of Jan 2 1988).

${ }^{8 a}$ L. H. Koole, M. H. P. van Genderen and H.M. Buck, J. A Chem. Soc. 109, 3916 (1987);

${ }^{\mathrm{b}}$ L.H. Koole, M.H.P. van Genderen, H. Frankena, H.J.I Kocken, J. A. Kanters and H.M. Buck, Proc. K. Ned. Aka Wet., Ser. B 89, 51 (1986) (communicated by H. M. Buck at th meeting of Nov 25, 1985).

${ }^{9 a}$ L.H. Koole, N. L.H. L. Broeders, M. H. P. van Genderer P. J. L. M. Quaedflieg, S. J. van der Wal and H. M. Buck, Pro K. Ned. kad. Wet., Ser. B 91, 245 (1988) (communicated H. M. Buck at the meeting of May 30,1988$)$;

b M.H.P. van Genderen, M. P. Hilbers, P.J.L.M. Quedfieg L. H. Koole and H. M. Buck, J. Am. Chem. Soc., submitted fo publication.

${ }^{10 a}$ M. H. P. van Genderen, L. H. Koole and H. M. Buck, Proc. Ned. Akad. Wet., Ser. B 90, 181 (1987) (communicated b H. M. Buck at the meeting of Jun 22, 1987);

b M. H. P. van Genderen, L. H. Koole and H.M. Buck, Proc. Ned. Akad. Wet., Ser. B 91, 171 (1988) (communicated H.M. Buck at the meeting of Nov 30,1987 ).

11 P. S. Miller, J. Yano, E. Yano, C. Carroll, K. Jayaraman an P. O.P. Ts'o, Biochemistry 18, 5134 (1979).

12 R. C. Pless and P. O. P. Ts'o, Biochemistry 16, 1239 (1977)

13 T. Atkinson and M. Smith in "Oligonucleotide Synthesis, Practical Approach", M.J. Gait, ed., IRL Press Ltd., Oxfo 1984, Chapter 3 and references cited therein.

14 L. J. McBride, R. Kierzek, S. L. Beaucage and M. H. Caruther J. Am. Chem. Soc. 108, 2040 (1986).

${ }^{15 a} C$. Gioeli and J. Chattopadhyaya, J. Chem. Soc., Che Commun. 263 (1982);

' J. Heikkilä and J. Chattopadhyaya, Acta Chem. Scand. B37, (1983);

c T. R. Webb and M.D. Matteucci, Nucleic Acids Res. 14, (1986);

d E. Happ, C. Scalf-Happ and S. Chladek, J. Org. Chem. 5387 (1987).

16 K. Wüthrich, "NMR of Proteins and Nucleic Acids", J. Wiley Sons, New York, 1986, Chapter 2.

17 W. Saenger, "Principles of Nucleic Acid Structure", Sprin Verlag, New York, 1984, Chapter 11.

18 See ref. 17, Chapter 9.

19 R. S. Cahn, C. Ingold and V. Prelog, Angew. Chemie 78, (1966).

${ }^{20}$ M. F. Summers, C. Powell, W. Egan, R. A. Byrd, W. D. Wils and G. Zon, Nucleic Acids Res. 14, 7421 (1986).

${ }^{21 a}$ See ref. 17 , Chapter 4;

${ }^{\mathrm{b}}$ Nomenclature for nucleic acid conformations follows IUPAC-IUB recommendations. See: Eur. J. Biochem. 131. (1983).
b.J.s

Effect

C. $A$ l

$K . K$.

Acids

N.C.

A. Rik

See $\mathrm{r}$

$M$. $H$.

Buck,

nicate

M. Ts New

$M . H$. for $\mathrm{pl}$

K. $J$. Natl.

${ }^{31 a} M . S z$

Lond

J. W.

32a G. D.

J. E.

Armit

(1974

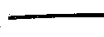


(1982 ${ }^{223}$ S. Wolfe, Acc. Chem. Res. 5, 102 (1972);

J. 203 "A.J. Kirby, "The Anomeric Effect and Related Stereoelectronic Effects at Oxygen", Springer Verlag, New York, 1983.

3 C. Altona, Recl. Trav. Chim. Pays-Bas 101, 9 (1982).

24 K. K. Chacko, K. Lindner, W. Saenger and P. S. Miller, Nucleic Acids Res. 11, 2801 (1983).

25 N. C. Seeman, J. N. Rosenberg, F. L. Suddath, J. J. P. Kim and A. Rich, J. Mol. Biol. 104, 109 (1976).

26 See ref. 17, Chapter 19.

27 M. H. P. van Genderen, L. H. Koole, H. M. Moody and H. M. Buck, Proc. K. Ned. Akad. Wet., Ser. B 91, 59 (1988) (communicated by H.M. Buck at the meeting of Nov 30, 1987).

${ }_{28}$ M. Tsuboi in "Conformation of Biopolymers", Academic Press, New York, 1967, Vol. II, pp. 689-702.

$1 \mathrm{H}$.

${ }_{29} M$. H. P. van Genderen and H. M. Buck, Biopolymers, accepted for publication.

renet

30 K. J. Breslauer, R. Frank, H. Blöcker and L. A. Marky, Proc. Natl. Acad. Sci. USA 83, 3746 (1986)

ad. S

31a M. Szekely in "From DNA to Protein", McMillan Press Ltd. London, 1980, Chapter 2;

Spir b J. Chase, Ann. Rev. Biochem. 55, 103 (1986)

ctors ${ }^{32 a}$ G. D. Brayer and A. McPherson, J. Mol. Biol. 169, 565 (1983);

blish J.E. Coleman, R. A. Anderson, R. G. Ratcliffe and I. $M$. Armitage, Biochemistry 15, 5419 (1976).

${ }_{33 a}$ D. C. Hinkle and M. Chamberlin, J. Mol. Biol. 70, 157 (1972);

Kuijpers ${ }^{\circ}$ W. F. Mangel and M. Chamberlin, J. Biol. Chem. 249, 2995

'enderen

91,205 (1974);
" $M$. Chamberlin in "RNA Polymerase", $R$. Losick and $M$. Chamberlin, eds., Cold Spring Harbor Press, New York, 1976, p. 159.

34 A. Schmitz and D.J. Galas; Nucleic Acids Res. 6, 111 (1979).

${ }^{35}$ P. H. von Hippel, D. G. Bear, W. D. Morgan and J.A. McSwiggen, Ann. Rev. Biochem. 53, 389 (1984).

36 S. L. Shaner, K. S. Lee, R. R. Burgess and M. T. Record, Jr., Cold Spring Harbor Symp. Quant. Biol. 47, 463 (1983).

37 200-HMz NMR spectra were measured on a Bruker AC-200 spectrometer at the Eindhoven University of Technology; 500and $600-\mathrm{MHz}$ spectra were measured on Bruker AM-500 and AM-600 spectrometers at the Dutch National High-Frequency NMR Facility in Nijmegen, The Netherlands.

38 C. A. G. Haasnoot and C. W. Hilbers, Biopolymers 22, 1259 (1983).

39 T. Maniatis, E.F. Fritsch and J. Sambrook, "Molecular Cloning", Cold Spring Harbor Laboratory, New York, 1982, pp. 461-463.

40 S. L. Beaucage and M. H. Caruthers, Tetrahedron Lett. 22, $1859(1981)$.

41 G. S. Ti, B. L. Gaffney and R. A. Jones, J. Am. Chem. Soc. 104, $1316(1982)$

42 J. Engels and A. Jäger, Angew. Chem. Suppl. 2010 (1982). 